\title{
EDITORIAL
}

\section{The Doctor as Historian}

THERE are some rewards in being Editor and of these probably the writing of the reviews of historical books submitted to the Journal is the greatest.

In this number we have reviewed two such works viz. "Wellington Pillar of State " by Lady Longford and "Napoleon, Bisexual Emperor"*. When we review books we find that quite inevitably we become aware of the author's background and personality. Thus as Lady Longford is a doctor's daughter and General Richardson is not only a doctor but is also the son of one, our thoughts turned towards the doctor as historian. To deal adequately with such a subject would merit a complete volume, and in a short editorial we can but touch on it.

To us the wonder has not been that so many doctors are historians but that so few are. Just consider what the historian needs -intelligence, industry, singleness of purpose, the ability to sift and weigh facts and fancies and separate truth from fiction, understanding, sympathy and compassion, but with the ability to remain objective and finally the ability to record in clear and easy prose the outcome of the research. Is not the above list of qualities identical with those required by any good doctor? We think so.

The old jeer that the medical profession is only half educated may have more truth in it than we care to believe, and may well be the explanation of this puzzling dearth of doctors who are historians. Be that as it may, we are very fortunate to have as the doyen of our Corps historians a medical officer as eminent as Lt. General Sir Neil Cantlie. For over a decade Sir Neil has been engaged in "The History of the Army Medical Services" which he has now completed. The history is to be published this autumn and as soon as practicable we will provide full details. To date no comprehensive History of the Army Medical Services prior to the formation of the Royal Army Medical Corps in 1898 has been produced, and Sir Neil's History will meet this long felt need.

* by Frank Richardson. 